\title{
Impact of the selected lactic acid bacteria on the growth of pathogens occurring in oilseed rape crops
}

\section{Wpływ wybranych bakterii fermentacji mlekowej na wzrost patogenów występujących w uprawie rzepaku}

\author{
Romuald Gwiazdowski ${ }^{1}$, Katarzyna Kluczyńska ${ }^{2}$, Daniela Gwiazdowska ${ }^{2}$
}

\section{Summary}

The aim of the study was to estimate the antagonistic properties of lactic acid bacteria (LAB) isolated from alfalfa silage and haylage. A total of 10 isolates of lactic acid bacteria were the objective of the study. The pathogens causing diseases of oilseed rape such as, Alternaria alternata, A. brassicae, A. brassicicola, Botryotinia fuckeliana, Leptosphaeria maculans, Pythium spp., Thanatephorus cucumeris and Sclerotinia sclerotiorum were indicator microorganisms. The studies revealed that isolates of LAB suppressed growth of selected indicator microorganism of Alternaria, Leptosphaeria, Pythium and Thanatephorus genera. In many cases, degradation of the surface of the aerial mycelium was also observed. The degree of inhibition growth of the indicator organism depended on the species and isolate of the pathogen as well as isolates of LAB.

Key words: lactic acid bacteria; antagonistic properties; oilseed rape

\section{Streszczenie}

Celem badań była ocena antagonistycznych właściwości izolatów bakterii fermentacji mlekowej, pochodzących z kiszonki paszowej na bazie lucerny i sianokiszonki. Przedmiot badań stanowiło 10 izolatów bakterii mlekowych. Mikroorganizmy wskaźnikowe stanowiły patogeny powodujące choroby rzepaku, w tym Alternaria alternata, A. brassicae, A. brassicicola, Botryotinia fuckeliana, Leptosphaeria maculans, Pythium spp., Thanatephorus cucumeris i Sclerotinia sclerotiorum. Badania wykazały, że izolaty bakterii mlekowych hamują rozwój wybranych patogenów rodzaju Alternaria, Leptosphaeria, Pythium i Thanatephorus. W wielu przypadkach obserwowano również degradację grzybni powietrznej. Stopień zahamowania rozwoju mikroorganizmu wskaźnikowego zależał od gatunku i izolatu patogena, jak również od poszczególnych izolatów bakterii mlekowych.

Słowa kluczowe: bakterie mlekowe; właściwości antagonistyczne; rzepak

\footnotetext{
Instytut Ochrony Roślin - Państwowy Instytut Badawczy

Władysława Węgorka 20, 60-318 Poznań

${ }^{2}$ Uniwersytet Ekonomiczny w Poznaniu

Wydział Towaroznawstwa

Al. Niepodległości 10, 61-875 Poznań

*corresponding author: r.gwiazdowski@iorpib.poznan.pl
} 


\section{Wstęp / Introduction}

Porażenie upraw patogenami wiąże się z wystąpieniem różnych chorób roślin, wpływających negatywnie na plon i jego jakość. Zarówno w przypadku rzepaku ozimego, jak i jarego do najistotniejszych czynników chorobotwórczych należy zaliczyć: Leptosphaeria maculans (anamorfa: Phoma lingam), Botryotinia fuckeliana (anamorfa: Botrytis cinerea), Sclerotinia sclerotiorum, Alternaria spp., Pythium spp. czy Thanatephorus cucumeris (anamorfa: Rhizoctonia solani). Są one przyczyną chorób o istotnym znaczeniu ekonomicznym, ponieważ straty, jakie powodują w plonach mogą sięgać nawet kilkudziesięciu procent (Mrówczyński i Pruszyński 2008). Ponadto mogą negatywnie wpływać na rozwój rzepaku, powodując zahamowanie jego wzrostu (Söchting i Verreet 2004; Zhao i wsp. 2004).

Rozwój patogenów porażających rzepak można obserwować przez cały okres wegetacji, a ich nasilenie w dużej mierze uzależnione jest od wystąpienia sprzyjających ich rozwojowi warunków meteorologicznych. Choroby rzepaku można ograniczać na wiele sposobów, między innymi przez odpowiednią agrotechnikę czy stosowanie środków chemicznych. W ostatnich dekadach poszukuje się również innych metod, w tym biologicznych. Ekologiczne trendy w uprawach roślin wraz z rosnącą świadomością o wysokim zanieczyszczeniu środowiska substancjami chemicznymi, zwiększają zainteresowanie alternatywnymi rozwiązaniami w ochronie roślin. Tym samym widoczny jest wzrost badań dotyczących, m.in. wykorzystania mikroorganizmów posiadających właściwości antagonistyczne, jak np.: bakterie rodzajów Bacillus, Enterobacter czy Pseudomonas (Kageyama i Nelson 2003; Danielsson i wsp. 2006). Wysoka aktywność antagonistyczna bakterii fermentacji mlekowej wskazuje, że również ich wykorzystanie może stanowić wartą uwagi alternatywę dla chemicznych środków stosowanych w ochronie roślin. Bakterie kwasu mlekowego produkują liczne aktywne metabolity, m.in. kwasy organiczne: mlekowy, octowy, bursztynowy lub inne związki, jak nadtlenek wodoru czy też bakteriocyny. Związki te odgrywają istotną rolę $\mathrm{w}$ antagonizmie bakterii fermentacji mlekowej w stosunku do innych mikroorganizmów, zarówno bakterii, jak i grzybów. Śledząc aktualne trendy w literaturze światowej, obserwuje się duży nacisk na rozwój prac związanych $\mathrm{z}$ poszukiwaniem izolatów charakteryzujących się określonymi właściwościami, takimi jak szeroki zakres aktywności antybakteryjnej czy też fungistatycznej (Gwiazdowska i Trojanowska 2005; Rouse i wsp. 2007; Czerwionka-Szaflarska i Romańczuk 2008; Franco i wsp. 2011).

W prezentowanej pracy przeprowadzono badania laboratoryjne, określające antagonistyczny potencjał izolatów bakterii mlekowych wyizolowanych z kiszonek paszowych wobec różnych gatunków patogenów powodujących choroby w uprawie rzepaku.

\section{Materiały i metody / Materials and methods}

\section{Material badawczy}

Przedmiot badań stanowiło 10 izolatów bakterii fermentacji mlekowej, pochodzących z kiszonki na bazie lucerny oraz z sianokiszonki. Izolaty wyselekcjonowano na podstawie wcześniejszych badań autorów (Gwiazdowski i wsp. 2013), w których oceniano aktywność wobec grzybów rodzaju Fusarium.

Jako mikroorganizmy wskaźnikowe wykorzystano 11 izolatów spośród ośmiu różnych gatunków: A. alternata BPR 1893, A. alternata KZF 13, A. brassicae BPR 1637, A. brassicae BPR 1678, A. brassicicola BPR 1735, B. fuckeliana BPR 187, B. fuckeliana KZF 37, L. maculans KZF 9, Pythium spp. BPR 1785, T. cucumeris BPR 1923 i S. sclerotiorum KZF 23. Patogeny pochodziły z kolekcji Banku Patogenów Roślin i Badania ich Bioróżnorodności oraz Zakładu Badania Środków Ochrony Roślin Instytutu Ochrony Roślin - Państwowego Instytutu Badawczego w Poznaniu.

\section{Ocena antagonistycznych wlaściwości bakterii mlekowych}

Właściwości antagonistyczne wybranych izolatów bakterii fermentacji mlekowej określano metodą dyfuzji studzienkowej. Bakterie mlekowe namnażano i przechowywano na płynnej pożywce MRS (de Man, Rogosa i Sharpe Broth firmy BIOCORP). Zawiesiny zarodników lub strzępek badanych organizmów przygotowano w jałowej soli fizjologicznej, a następnie wysiewano metodą zalewową z wykorzystaniem pożywki PDA (Potato Dextrose LAB-

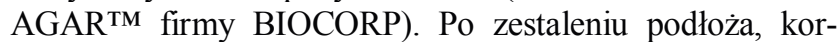
koborem wycinano studzienki o średnicy $10 \mathrm{~mm}$. Następnie do studzienek wprowadzano $100 \mu 1$ 48-godzinnej hodowli izolatów bakterii mlekowych o gęstości $10^{9} \mathrm{jtk} / \mathrm{ml}$. Inkubację płytek prowadzono w temperaturze pokojowej (około $20^{\circ} \mathrm{C}$ ) w warunkach tlenowych przez okres 10 dni. Po zakończeniu inkubacji mierzono strefy zahamowania wzrostu organizmów wskaźnikowych wokół studzienek w mm.

\section{Określenie poziomu produkcji kwasu mlekowego przez bakterie mlekowe}

Oznaczenie stężenia kwasu mlekowego wytwarzanego przez badane bakterie wykonano metodą HPLC (highperformance liquid chromatography). Do jałowych probówek eppendorf o pojemności $2 \mathrm{ml}$ wprowadzono $2 \mathrm{ml}$ hodowli badanych bakterii, następnie odwirowano je (10 $000 \mathrm{rpm}, 10 \mathrm{~min}$ ) w wirówce Centrifuge 5804R, Eppendorf AG. Płyn znad osadu przesączono przy użyciu filtrów mikrobiologicznych HPLC Millex Syringe-driven do jałowych probówek. Zawartość kwasu mlekowego w próbkach oznaczano na chromatografie cieczowym firmy Merck-Hitachi (zestaw: automatyczny podajnik prób MerckHitachi L-7250, pompa Merck-Hitachi L-7100). Do oznaczeń używano kolumny Animex HPX-87H $300 \times 7,8 \mathrm{~mm}$ (BIO-RAD). Jako eluent stosowano 0,005 $\mathrm{M} \mathrm{H}_{2} \mathrm{SO}_{4}$, przy przepływie $0,8 \mathrm{ml} / \mathrm{min}$. Jako standard stosowano roztwór kwasu mlekowego (5 g/l). Oznaczenie prowadzono w temperaturze $30^{\circ} \mathrm{C}$. Identyfikacji dokonano metodą standardu zewnętrznego z wykorzystaniem powierzchni i wysokości pików (pomiar i interpretacja komputerowa).

\section{Analiza statystyczna}

Analizę statystyczną uzyskanych wyników przeprowadzono z wykorzystaniem programu STATISTICA v. 10. Analiza obejmowała obliczenie wartości średniej z trzech 
równoległych powtórzeń i odchylenia standardowego. Istotność różnic między wartościami średnimi określano za pomocą testu t-Studenta. W celu określenia stopnia powiązań między aktywnością fungistatyczną a ilością wytworzonego kwasu mlekowego obliczono współczynnik korelacji Pearsona. Wszystkie hipotezy statystyczne weryfikowano na poziomie istotności $\mathrm{p}=0,05$.

\section{Wyniki i dyskusja / Results and discussion}

Prezentowane wyniki badań dotyczą antagonistycznego oddziaływania bakterii fermentacji mlekowej w stosunku do wybranych gatunków patogenów powodujących choroby rzepaku. We wcześniejszych badaniach autorów spośród 46 izolatów bakterii mlekowych wybrano 10 o największej aktywności antagonistycznej wobec 7 gatunków grzybów rodzaju Fusarium (Gwiazdowski i wsp. 2013). Analiza wyników przeprowadzonych badań pozwoliła na wyselekcjonowanie izolatów bakterii mlekowych, które wykazywały wysoką aktywność hamującą wzrost $F$. langsethiae, $F$. avenaceum i $F$. poae. Nieco słabszą aktywność stwierdzono w stosunku do grzybów $F$. oxysporum oraz
$F$. equiseti. Dane literaturowe $\mathrm{z}$ różnych ośrodków badawczych, jak również badania własne autorów dowodzą, że bakterie fermentacji mlekowej mogą wykazywać szerokie właściwości antybakteryjne, jak i fungistatyczne wobec zróżnicowanych grup mikroorganizmów (Rouse i wsp. 2007; Gwiazdowski i Gwiazdowska 2008; Franco i wsp. 2011; Gwiazdowski i wsp. 2013). Większość badań dotyczy jednak problematyki żywności, natomiast przydatność tych mikroorganizmów w ochronie roślin jest słabo poznana. Wyniki doświadczeń prezentujących antagonistyczną aktywność badanych bakterii przedstawiono w tabeli 1 .

Na podstawie analizy wyników stwierdzono zróżnicowane oddziaływanie wybranych izolatów bakterii mlekowych wobec testowanych patogenów. Stopień hamowania wzrostu zależał w dużej mierze od gatunku patogena, ale także od izolatu bakterii mlekowych. Podczas analizy wyników badań zaobserwowano wyraźne strefy hamowania wzrostu, jak również ograniczony rozwój grzybni powietrznej (rys. 1). W celu dokładnego scharakteryzowania oddziaływania bakterii, mierzalne strefy oddziaływania zapisano w milimetrach, wyszczególniono również strefy oddziaływania na grzybnię powietrzną $(+)$, lub całkowity brak aktywności antagonistycznej (0).

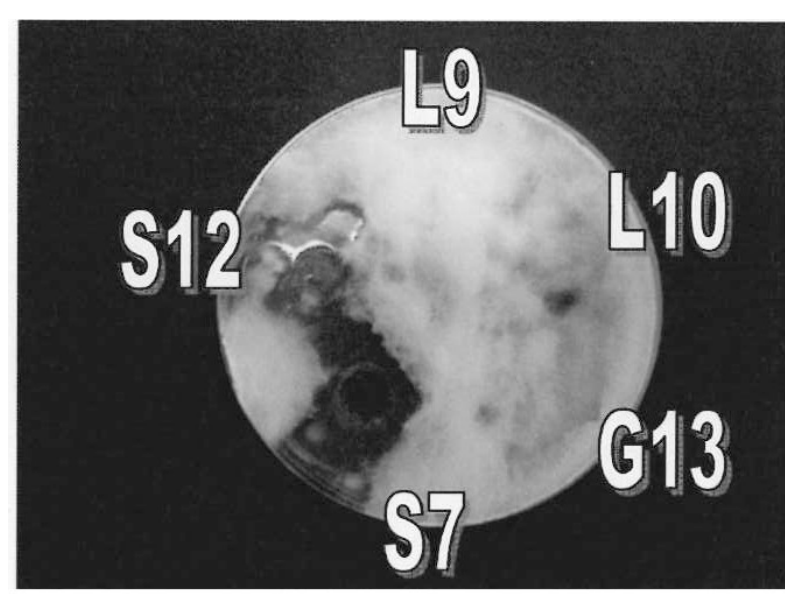

Pythium spp.

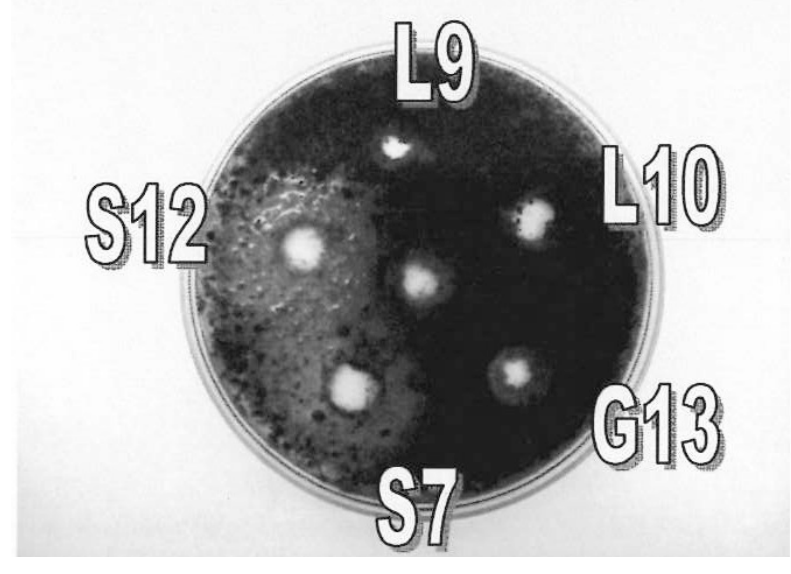

Alternaria brassicicola

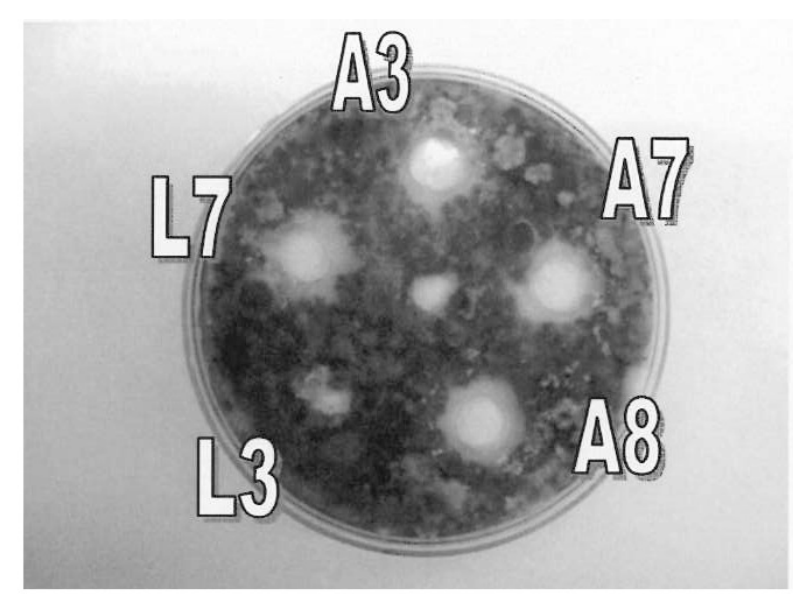

Alternaria brassicae

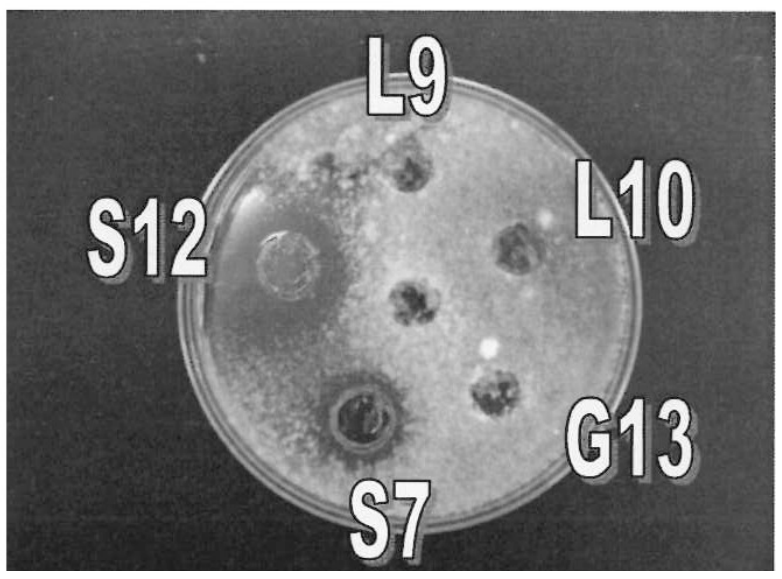

Leptosphaeria maculans

Rys. 1. Antagonistyczne właściwości wyselekcjonowanych izolatów wobec patogenów rzepaku

Fig. 1. Antagonistic properties of the selected lactic acid bacteria isolates against oilseed rape pathogens 


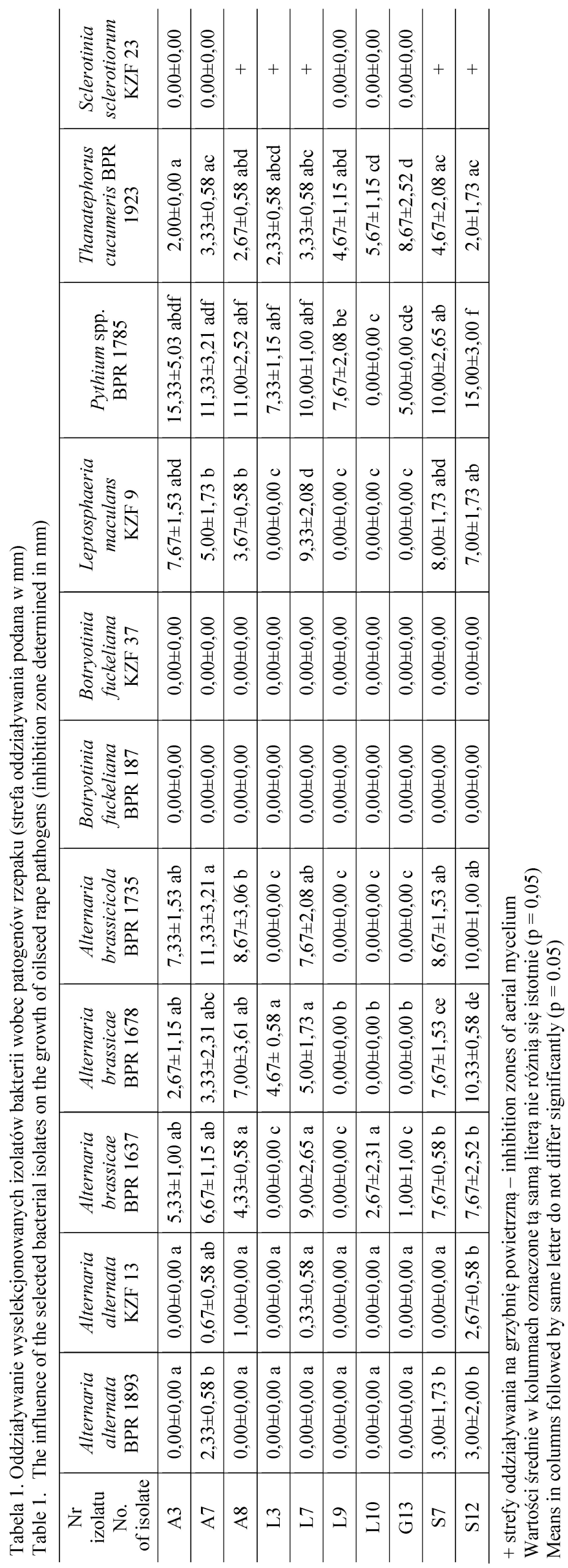




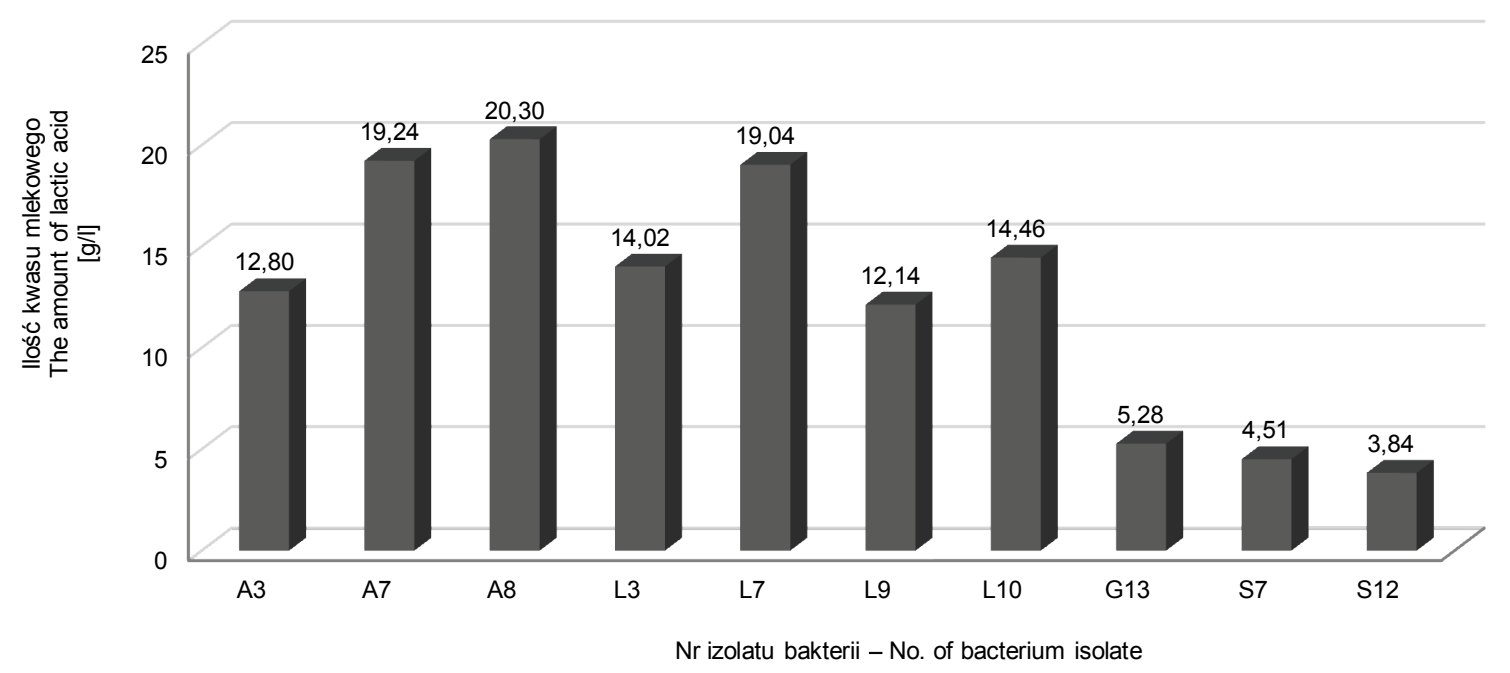

Rys. 2. Produkcja kwasu mlekowego przez badane izolaty bakterii [g/l]

Fig. 2. The production of lactic acid by the tested bacterial isolates [g/l]

Spośród badanych patogenów największą wrażliwość na działanie bakterii fermentacji mlekowej wykazały gatunki: A. alternata, A. brassicae, A. brassicicola, L. maculans, Pythium spp. oraz T. cucumeris. W najmniejszym stopniu hamowany był grzyb $S$. sclerotiorum, natomiast B. fuckeliana nie wykazywał wrażliwości na działanie bakterii mlekowych. Słabe oddziaływanie bakterii fermentacji mlekowej w stosunku do B. fuckeliana obserwowano również we wcześniejszych badaniach autorów, jednak oddziaływanie wobec S. sclerotiorum (Gwiazdowski i Gwiazdowska 2008) było silniejsze niż bakterii wyizolowanych z kiszonek. W prezentowanej pracy w przypadku niektórych gatunków grzybów, m.in. S. sclerotiorum, zaobserwowano zmiany barwy i struktury grzybni powietrznej wokół studzienek na skutek oddziaływania bakterii mlekowych. Najaktywniej działającymi spośród badanych bakterii mlekowych były izolaty: A3, A7, A8, L7, S7 oraz S12. Bakterie te wyróżniała zarówno wysoka aktywność antagonistyczna, jak i szerokie spektrum działania względem badanych rodzajów oraz izolatów organizmów wskaźnikowych. Obserwowane barwne zmiany struktury grzybni, jak również degradacja grzybni powietrznej mogą świadczyć o zaburzeniu procesu wzrostu grzybni i prawidłowego zarodnikowania.

Wytwarzanie kwasu mlekowego należy do cech definiujących bakterie fermentacji mlekowej, a ilość produkowanego kwasu w istotny sposób wpływa na przeciwdrobnoustrojową aktywność tych mikroorganizmów (Van Winsen i wsp. 2000; Missotten i wsp. 2009). Dlatego w niniejszej pracy określony został poziom produkcji kwasu mlekowego przez poszczególne izolaty. Jak wykazały badania wszystkie testowane izolaty bakterii wytwarzały kwas mlekowy, jednak jego poziom w poszczególnych próbkach był bardzo zróżnicowany (rys. 2). Najwyższe stężenie kwasu mlekowego, kształtujące się na poziomie około 14,02-20,30 g/l odnotowano w hodowlach izolatów L3, L10, L7, A7 i A8, przy czym izolaty wytwarzające największą ilość kwasu mlekowego to: A8
(20,31 g/l) i A7 (19,24 g/1). W przypadku 3 izolatów: S12, S7 oraz G13 zaobserwowano małą ilość kwasu mlekowego, kształtującą się na poziomie 3,84-5,28 g/l. Należy przy tym podkreślić, że dwa z nich, S7 i S12 wykazywały dużą aktywność antagonistyczną, co oznacza, że kwas mlekowy nie był jedynym metabolitem decydującym o właściwościach antagonistycznych. Analiza statystyczna nie wykazała korelacji między ilością wytworzonego kwasu a aktywnością fungistatyczną badanych szczepów, o czym świadczy niski współczynnik korelacji $(\mathrm{R}=0,03)$. Potwierdzają to dane literaturowe, wskazując na udział innych składników w antagonizmie bakterii fermentacji mlekowej, takich jak: bakteriocyny, cykliczne dipeptydy czy kwas fenylomlekowy (Ström i wsp. 2002; Schnürer i Magnusson 2005).

Przeprowadzone badania potwierdzają możliwość praktycznego wykorzystania wyselekcjonowanych izolatów bakterii mlekowych w biologicznej kontroli, zarówno jako pojedyncze szczepy, jak również jako element złożonych biopreparatów. Antagonistyczna aktywność wybranych szczepów bakterii mlekowych może znaleźć potencjalnie praktyczne zastosowanie, m.in. w ochronie roślin.

\section{Wnioski / Conclusions}

1. Wyselekcjonowane szczepy bakterii mlekowych wykazywały działanie antagonistyczne wobec: A. alternaria, A. brassicae, L. maculans, Pythium spp. i T. cucumeris. Stopień zahamowania rozwoju mikroorganizmu wskaźnikowego uzależniony był zarówno od gatunku, jak i izolatu patogena.

2. Szerokie spektrum antagonistycznej aktywności wybranych szczepów bakterii mlekowych może znaleźć potencjalnie praktyczne zastosowanie, m.in. w ochronie roślin. 


\section{Literatura / References}

Czerwionka-Szaflarska M., Romańczuk B. 2008. Probiotyki - jakie, komu, kiedy? Przewodnik Lekarza 11 (1): 214-219.

Danielsson J., Reva O., Meijer J. 2006. Protection of oilseed rape (Brassica napus) toward fungal pathogens by strains of plantassociated Bacillus amyloliquefaciens. Microbial Ecology 54 (1): 134-140.

Franco T.S., Garcia S., Hirooka E.Y., Ono Y.S., dos Santos J.S. 2011. Lactic acid bacteria in the inhibition of Fusarium graminearum and deoxynivalenol detoxification. Journal of Applied Microbiology 111 (3): 739-748.

Gwiazdowski R., Gwiazdowska D. 2008. Oddziaływanie mieszanych kultur bakterii fermentacji propionowej i mlekowej na grzyby patogeniczne. [Impact of mixed bacterial cultures of propionic and lactic fermentation on pathogenic fungi]. Progress in Plant Protection/Postępy w Ochronie Roślin 48 (2): 285-286.

Gwiazdowski R., Kluczyńska K., Gwiazdowska D. 2013. Fungistatyczne właściwości bakterii mlekowych wyizolowanych z kiszonek. [Fungistatic activity of lactic acid bacteria isolated from silage]. Progress in Plant Protection/Postępy w Ochronie Roślin 53 (3): $505-509$.

Gwiazdowska D., Trojanowska K. 2005. Bakteriocyny - właściwości i aktywność przeciwdrobnoustrojowa. Biotechnologia 68 (1): $114-130$.

Kageyama K., Nelson E.B. 2003. Differential inactivation of seed exudates stimulation of Pythium ultimum sporangium germination by Enterobacter cloacae influences biological control efficacy on different plant species. Applied and Environmental Microbiology 69 (2): 1114-1120.

Missotten J.A.M., Goris J., Michiels J., Van Coillie E., Herman L., De Smet S., Dierick N.A., Heyndrickx M. 2009. Screening of isolated lactic acid bacteria as potential beneficial strains for fermented liquid pig feed production. Animal Feed Science and Technology 150 (1-2): 122-138.

Mrówczyński M., Pruszyński S. (red.). 2008. Integrowana produkcja rzepaku ozimego i jarego. Inst. Ochr. Roślin, Poznań, $106 \mathrm{ss}$.

Rouse S., Harnett D., Vaughan A., van Sinderen D. 2007. Lactic acid bacteria with potential to eliminate fungal spoilage in foods. Journal of Applied Microbiology 104 (3): 915-923.

Schnürer J., Magnusson J. 2005. Antifungal lactic acid bacteria as biopreservatives. Trends in Food Science and Technology 16: 70-78.

Söchting H.P., Verreet J.A. 2004. Effects of different cultivation systems (soil management, nitrogen fertilization) on the epidemics of fungal diseases in oilseed rape (Brassica napus L. var. napus). Journal of Plant Diseases and Protection 111 (1): 1-29.

Ström K., Sjögren J., Broberg A., Schnürer J. 2002. Lactobacillus plantarum MiLAB 393 produces the antifungal cyclic dipeptides cyclo(LPhe-L-Pro) and cyclo(L-Phe-trans-4-OH-L-Pro) and 3-phenycllactic acid. Applied and Environmental Microbiology 68: $4322-4327$.

Van Winsen R.L., Lipma L.J.A., Biesterveld S., Urlings B.A.P., Snijders J.M.A., Van Knapen F. 2000. Mechanism of Salmonella reduction in fermented pig feed. Journal of the Science and Food Agriculture 81: 342-346.

Zhao J., Peltier A.J., Meng J., Osborn T.C., Grau C.R. 2004. Evaluation of Sclerotinia stem rot resistance in oilseed Brassica napus using a petiole inoculation technique under greenhouse conditions. Plant Dissease 88 (9): 1033-1039. 